\title{
A stroke-ellátás hazai eredményei a nemzetközi adatok tükrében
}

\author{
Szőcs Ildikó dr. ${ }^{1}$ - Bereczki Dániel dr. ${ }^{1}$ - Belicza Éva dr. ${ }^{2}$ \\ Semmelweis Egyetem, ${ }^{1}$ Általános Orvostudományi Kar, Neurológiai Klinika, \\ ${ }^{2}$ Egészségügyi Menedzserképző Központ, Budapest
}

\begin{abstract}
Bevezetés: A 2010-2014 között futó EuroHOPE FP7-es kutatási projekt többek között a stroke-ellátás eredményességének és hatékonyságának elemzésével foglalkozott. Célkitüzés: A dolgozat célja a hazai adatok bemutatása és öszszehasonlítása a nemzetközi eredményekkel, a különbségek lehetséges okainak feltárása. Módszer: Finnország, Hollandia, Magyarország, Olaszország, Skócia, Svédország hospitalizált ischaemiás stroke-eseteinek jellemzése standard módon előállított indikátorokkal történt. Adatforrásként a regulárisan gyújtött adatok szolgáltak. A hazai elemzések 2005-2009-re, a nemzetközi összehasonlítások 2008-ra vonatkozóan készültek el nyers mutatókkal és többváltozós logisztikus regressziós módszerrel történő kockázatkiegyenlítési eljárással. Eredmények: Hazánkban a stroke-incidencia a finn és olasz értékek kétszerese volt (43,3/10 000 lakos). A komorbiditás nem mutatott lényeges különbségeket az országok között. Magyarországon a stroke-betegek harmadannyian $(19,9 \%)$ váltottak ki véralvadásgátlókat, mint a finnek. A magyar betegek halálozása az elemzett országok között a legrosszabb, harmaduk egy éven belül meghal. Ennek hátterében a hazai elsődleges prevenció elégtelensége, az akut stroke-betegek felvételkori súlyosabb állapota, illetve a kórházi ellátás, az elbocsátás utáni rehabilitáció és beteggondozás hiányosságai állhatnak. Következtetés: Javasolt a hazai rossz eredmények oki kutatása és ezekre alapozott intézkedések kezdeményezése. Orv. Hetil., 2016, $157(41), 1635-1641$.
\end{abstract}

Kulcsszavak: stroke, incidencia, komorbiditás, gyógyszerfelírás, halálozás

\section{Results of stroke care in Hungary in the frame of international comparison}

Introduction: The EuroHOPE FP7 project analysed the effectiveness and efficiency of stroke care between 2010 and 2014. Aim: The study introduces Hungarian data in comparison with international results and explores the causes of differences. Method: The analysis was performed on data available from regular data collection in Finland, The Netherlands, Hungary, Italy, Scotland, and Sweden, with standardized indicators. Hungarian data was analysed between 2005 and 2009, and the international benchmarking in 2008, with multivariate logistic regression analysis for risk adjustment. Results: Stroke incidence in Hungary was the double of the Italian or Finnish results $(43.3 / 10,000$ inhabitants), while comorbidities did not differ among countries. In Hungary, $19.9 \%$ of patients purchased anti-coagulants, one-third of the rate in Finland. One-year mortality in Hungary was 30\%, the worst among the countries. Possible causes are inadequate prevention, more severe status of patients, and deficiencies of hospital care and rehabilitation. Conclusion: Causal analysis of these results and corrective measurements are recommended.

Keywords: stroke, incidence, comorbidity, drug prescriptions, mortality

Szöcs, I., Bereczki, D., Belicza, É. [Results of stroke care in Hungary in the frame of international comparison]. Orv. Hetil., 2016, 157(41), 1635-1641.

(Beérkezett: 2016. július 7.; elfogadva: 2016. augusztus 11.)

\section{Rövidítések}

ÁEEK = Állami Egészségügyi Ellátó Központ; BNO = Betegségek Nemzetközi Osztályozása; ESKI = Egészségügyi Stratégiai Kutatóintézet; EuroHOPE = European Healthcare Outcomes, Performance and Efficiency FP7-es kutatási projekt
(2010-2014); FIN = Finnország; HUN = Magyarország; ITA = Olaszország (Torino és Lazio tartomány); NET = Hollandia; OEP = Országos Egészségbiztosítási Pénztár; SCO = Skócia; SWE = Svédország; taj = társadalombiztosítási azonosítójel 
A stroke-halálozás tekintetében Európa különböző országai között hosszú ideje jelentős különbség van. KeletEurópában az eleve magasabb stroke-halálozás tovább romlott az 1980-as évek végéig, majd enyhén csökkenni kezdett [1], de még mindig több mint egy évtizeddel elmarad Nyugat-Európa országainak adataihoz képest $[2,3]$. A jelentős mortalitási különbségek, valamint a kezelési és kimeneteli adatok szegényessége mind arra utalnak, hogy szükség lenne standardizált módszereken alapuló nemzetközi adatbázis létrehozására, amelynek segítségével feltárhatnánk az említett különbségek okait.

Korábban számos felmérésben használták az esethalálozást, mint a kórházak teljesítményértékelésére is alkalmas kimeneteli indikátort. A nemzetközi összehasonlításokhoz használt adatokat egyéni kórházi regiszterekből vagy ezekre alapozott nemzeti adatbázisokból generálták. Ezeket számos buktató kíséri a felmérésben részt vevő kórházak korlátozott száma, az eltérő betegösszetételek, jelentési szokások vagy az alkalmazott módszerek különbségei miatt.

A European Healthcare Outcomes, Performance and Efficiency (EuroHOPE) tanulmány erőssége, hogy különböző nemzeti adatbázisokra támaszkodva standardizált módszerekkel, egyedi adatokból nyert nemzetközi összehasonlításra is alkalmas mutatókat.

Az Európa országai közt ismert, számottevő szociokulturális, gazdasági, egészségszervezési különbségből kiindulva jelentős eltérés várható az országos egészségügyi ellátórendszerek eredményessége, szúkebben értelmezve a stroke esethalálozása tekintetében is [4]. Dolgozatunk célja a hazai adatok bemutatása és összehasonlítása a nemzetközi eredményekkel, a különbségek lehetséges okainak feltárása.

\section{Módszer}

A EuroHOPE kutatás rendszeresen gyưjtött, esetszintű, úgynevezett adminisztratív adatokra támaszkodott. Az Országos Egészségbiztosítási Pénztár a személyek azonosítására alkalmatlan egyedi azonosítókkal ellátva kutatási, elemzési céllal rendszeresen megküldi állományait korábban az Egészségügyi Stratégiai Kutatóintézet (ESKI), most az Állami Egészségügyi Ellátó Központ (ÁEEK) számára. Kutatásunkhoz a hazai esetszintű adatokat az ESKI bocsátotta rendelkezésünkre.

A stroke-betegek adatait a kórházi igénybevételi adatokat tartalmazó adatbázisból nyertük. A halálozás dátumát a halálozás helyétől függetlenül vettük figyelembe a vonatkozó adatbázis adatai alapján. A gyógyszer-felhasználási adatok a vényre kiváltott gyógyszerek állományából származnak. Az incidenciaértékek számításához a kor és nem szerinti lakossági adatokat az Organisation for Economic Co-operation and Development (OECD) statisztikai moduljából [5] nyertük.

A hazai stroke-eseményeket 2005-2009 között elemeztük. A EuroHOPE projektben közremúködő országok adatai közül az utolsó elérhető év adatait vettük fi- gyelembe, így Finnország (FIN), Skócia (SCO), Olaszország (ITA, Lazio tartomány és Torino), Hollandia (NET), Svédország (SWE) 2008-as eredményeit vetettük össze a hazai értékekkel. Skócia és Hollandia a gyógyszerek kiváltására vonatkozóan nem vagy nem elég részletes adatokat közölt, így ezeket az országokat a gyógyszerfogyasztásra vonatkozó elemzésekben nem vettük figyelembe.

A stroke-esetek azonosítása a EuroHOPE stroke-betegekre vonatkozó feldolgozási és elemzési protokollja alapján készült valamennyi közremúködő országban [6, 7]. A vizsgálatba azokat a 18 évnél idősebb betegeket vontuk be, akiknél az ápolást indokló fódiagnózis BNO 10-es kódja akut kórházi osztályon I60, I61, I63 vagy I64 volt, és a megelőző 365 napban nem volt ilyen fődiagnózis kóddal ismert osztályos ellátásuk. Kizártuk a külföldi állampolgárokat és azokat a betegeket, akik nem rendelkeztek érvényes taj-számmal.

A stroke-eset kezdete a stroke fódiagnózist tartalmazó első akut osztályos ellátás volt (indexfelvétel). Ha a betegnek a távozás napján vagy másnap új osztályos vagy kórházi felvétele volt, az ellátási eseményeket összevontuk. Kizártuk a további elemzésből azokat a betegeket, akiknél az így definiált első kórházi esemény (indexesemény) időtartama 90 napnál hosszabb volt. A részletes elemzéseket a legnagyobb esetszámot képviselő ischaemiás stroke- (I63) betegekre vonatkozóan végeztük el.

A komorbiditási vizsgálatokhoz olyan diagnózisok kerültek kiemelésre, amelyek befolyásolhatják a stroke incidenciáját, kezelését és/vagy a betegek halálozását. A komorbiditást két megközelítés együttes alkalmazásával határoztuk meg. Egyrészt felmértük az indexfelvételt megelőző 365 napon belül a beteg különböző kórházi ellátásai során rögzített diagnózisokat a diagnózis típusától függetlenül. A komorbiditás másik információforrását adott betegségre specifikus, az indexfelvételt megelőző 365 napon belül vényre kiváltott gyógyszerek jelentették. A magyarországi vényadatok csak hónapos bontásban voltak elérhetók, így a kiváltás napjaként a hónap 15. napját tekintettük közelítő módszerként.

Azon betegek körében, akik legalább 90 nappal az indexfelvételt követően életben voltak, felmértük a kórházi távozást követő 365 nap során kiváltott gyógyszereket. A legalább egyszer receptre kiváltott gyógyszereket vettük számításba függetlenül az ismételt kiváltástól és a megvásárolt dózistól. A gyógyszereket hatóanyag szerint határoztuk meg és ATC-kódjaik alapján azonosítottuk. Az alkalmazott kódokat a jelen lapszámban közölt módszertani cikkünk tartalmazza.

A halálozás dátumát a hivatalos taj-nyilvántartás alapján határoztuk meg. Nem vettük figyelembe a halálozás helyét és okát, így a stroke-betegek halálozásáról és nem stroke miatti halálozásról beszélhetünk.

Az életkor és a nem szerinti különbségek kiegyenlítésére logisztikus regressziós módszert alkalmaztunk a halálozási mutatók és a kórházi távozást követően kiváltott gyógyszerek elemzéséhez. 
Hospitalizált stroke-betegek jellemzői Magyarországon (20052009 ) és néhány európai országban (2008)

\begin{tabular}{|c|c|c|c|c|c|c|c|}
\hline \multirow[t]{2}{*}{ Ország* } & \multirow[t]{2}{*}{ Év } & \multirow{2}{*}{$\begin{array}{l}\text { Összes } \\
\text { stroke- } \\
\text { eset } \\
\text { száma } \\
\text { (fó) }\end{array}$} & \multicolumn{5}{|c|}{ Ischaemiás stroke } \\
\hline & & & Fö & $\begin{array}{l}\text { Rész- } \\
\text { arány } \\
(\%)\end{array}$ & $\begin{array}{l}\text { Inciden- } \\
\text { cia } \\
\text { (/10000 } \\
\text { 18-X éves } \\
\text { lakos) }\end{array}$ & $\begin{array}{l}\text { Férfiak } \\
(\%)\end{array}$ & $\begin{array}{l}\text { Átlag- } \\
\text { életkor } \\
\text { (élet- } \\
\text { év) }\end{array}$ \\
\hline HUN & 2005 & 46455 & 39868 & 85,8 & 49,0 & 48,0 & 69,3 \\
\hline HUN & 2006 & 42936 & 37269 & 86,8 & 45,7 & 47,5 & 69,2 \\
\hline HUN & 2007 & 39146 & 34148 & 87,2 & 41,8 & 47,6 & 69,5 \\
\hline HUN & 2008 & 40119 & 35349 & 88,1 & 43,3 & 47,3 & 69,4 \\
\hline HUN & 2009 & 41703 & 37096 & 89,0 & 45,4 & 46,8 & 69,4 \\
\hline FIN & 2008 & 11297 & 8825 & 78,1 & 20,8 & 51,7 & 72,4 \\
\hline ITA & 2008 & 13231 & 8718 & 65,9 & 21,0 & 54,1 & 73,7 \\
\hline NET & 2008 & 20396 & 12266 & 60,1 & n. a. & 51,5 & 71,7 \\
\hline SCO & 2008 & 8189 & 3900 & 47,6 & 9,5 & 50,2 & 72,9 \\
\hline SWE & 2008 & 24804 & 19189 & 77,4 & 26,2 & 50,2 & 76,0 \\
\hline
\end{tabular}

*FIN = Finnország; HUN = Magyarország; ITA = Olaszország (Torino és Lazio tartomány); NET = Hollandia; SCO = Skócia; SWE = Svédország; n. a. = nincs adat

Az indikátorok előállításához és a többváltozós elemzések elkészítéséhez a EuroHOPE konzorciumi vezetője biztosította a Stata statisztikai programhoz készített feldolgozási fájlokat. A módszertan részletes ismertetése az Orvosi Hetilap jelen számában kerül közlésre.

\section{Eredmények}

Magyarországon stroke miatt az évente hospitalizált betegek száma 2005-2009 között mérsékelten csökkent. A legkevesebb stroke-beteget 2007-ben vették fel a kórházak, amikor jelentős ellátórendszeri átalakítás miatt általánosan is csökkent a kórházi felvételek száma. Az ischaemiás stroke-ot elszenvedett betegek aránya magas, és közel azonos a vizsgált időszakban, 86-89\% között mozog (1. táblázat).

A teljes népességre számított előfordulási gyakoriság Magyarországon kifejezetten magasnak mondható, 10000 lakosból egy év során legalább 40 fó kerül ischaemiás stroke miatt kórházi felvételre. Nemzetközi összehasonlítást 2008-ra vonatkozóan végeztünk. Az ischaemiás stroke incidenciaértékei jelentős különbséget mutatnak a projekt többi országával. A két skandináv államban, Finnországban és Svédországban, valamint Olaszországban közel hasonlóak az értékek, és mintegy felét mutatják a hazai adatoknak. Igen alacsony a skót incidencia, a hazai érték alig negyedét teszi ki, azonban itt az ischaemiás stroke részaránya is lényegesen alacsonyabb a többi országhoz képest: csupán 47,6\% (1. táblázat). Hollandia adatai részlegesek voltak, nem minden kórház vett részt a felmérésben, így rájuk vonatkozóan nem tudtunk incidenciát számolni.

A stroke bekövetkezte előtt ismert komorbiditási mutatókat csak azoknak az országoknak a bevonásával számoltuk ki, amelyek gyógyszeradatbázissal is rendelkeztek. A magyar adatok mellett így a finn, svéd és olasz arányszámokat tüntettük fel (1. ábra). Az ismert másodlagos betegségek gyakorisági sorrendje és nagyságrendje a négy országban hasonló. A leggyakoribb kórképek a magas vérnyomás és a diabetes.

Négy hatóanyagcsoportban vizsgáltuk a stroke után receptre kiváltott gyógyszereket azok körében, akik az indexfelvételt követő 90. napon életben voltak. Magyarországon 2005-2009 között emelkedett a vérlemezkeés véralvadásgátló, illetve a lipidcsökkentő szer legalább egyszer történő kiváltása. Alig változott a diabetes gyógyszereinek használata, és mérsékelten csökkent a magas vérnyomás kezelésére alkalmazott gyógyszerek vásárlása (2. ábra). Az antiaggregáns-antikoaguláns csoportba kiválasztott gyógyszereket nemcsak a jelentőségük, hanem a felírási rendjük is meghatározta. Így például, mivel az acetilszalicilsav (aszpirin) nem vényköteles, erre vonatkozó adatokat nem tudtunk szerezni. A warfarin használata minimális: míg a clopidrogel használata 9,1\%-ról 14,1\%-ra nőtt az időszak végére, a warfarin 0,4\%-ról változott 1,6\%-ra. Vizsgáltuk azt is, hogyan változik az ischaemiás stroke miatti hospitalizáció előtti és utáni 365 napban a gyógyszervásárlás rátája, azonban említésre érdemes különbséget nem észleltünk (3. ábra).

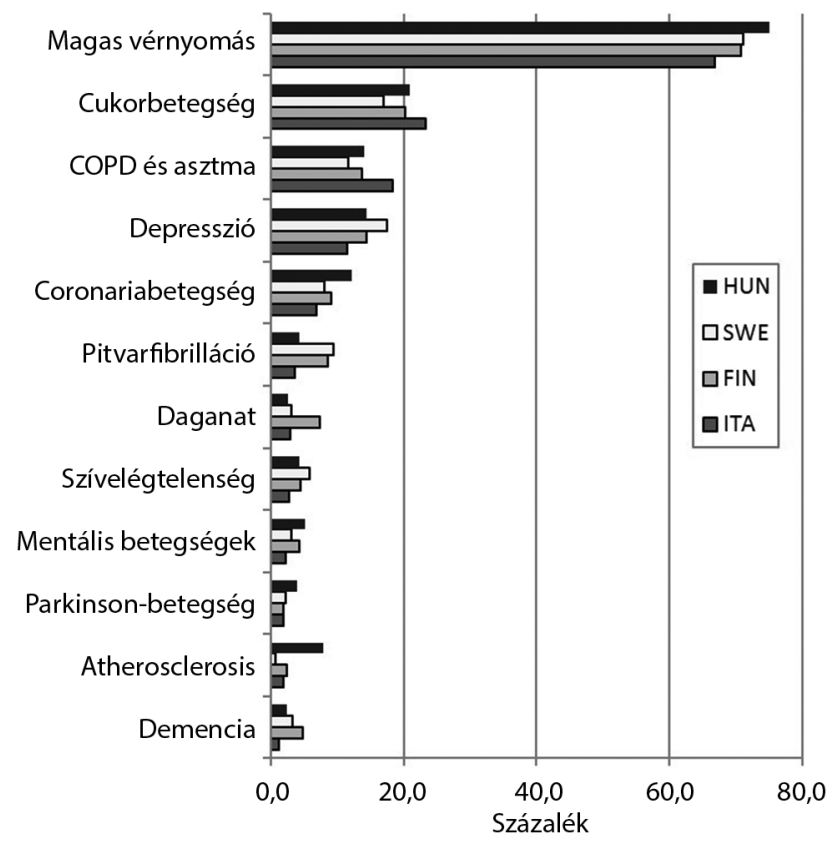

1. ábra \begin{tabular}{|l}
$\begin{array}{l}\text { Ismert morbiditás a megelőző } 365 \text { nap során rögzített diagnó- } \\
\text { zisok és vásárolt gyógyszerek alapján országonként*, ischaemiás } \\
\text { stroke, } 2008\end{array}$ \\
*FIN = Finnország; HUN = Magyarország; ITA = Olaszország \\
(Torino és Lazio tartomány); SWE = Svédország
\end{tabular} 


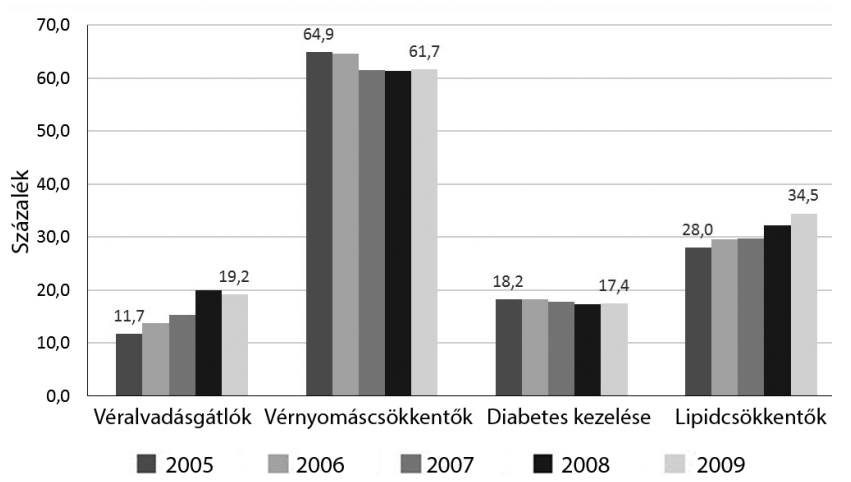

2. ábra

Kiváltott gyógyszerek kor és nem szerint standardizált aránya ishaemiás stroke miatti kórházi felvételt követő 365 napon belü a legalább 90 napot túlélt betegek körében 2005-2009 között, Magyarország

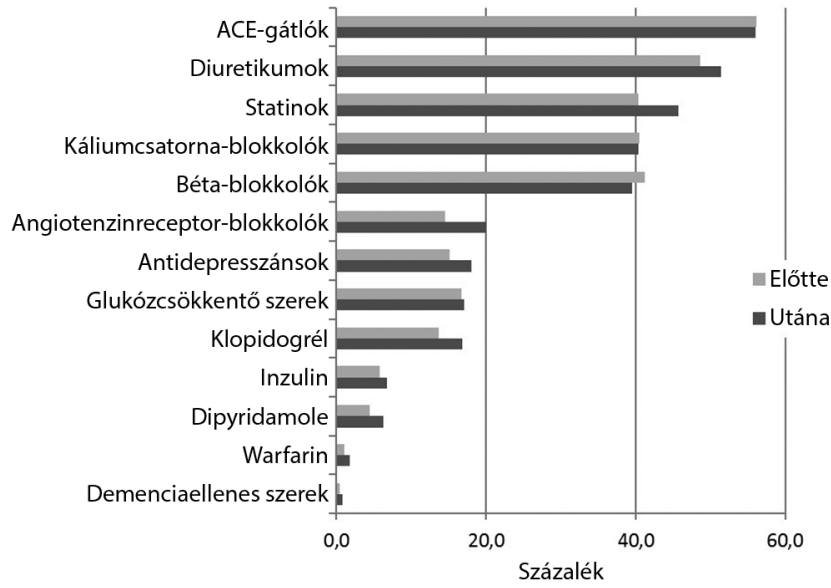

3. ábra

Gyógyszerek kiváltási aránya az indexfelvételt megelőző 365 napban és az indexfelvétel utáni 365 napon belül a legalább 365 napot túlélők körében, Magyarország, 2009

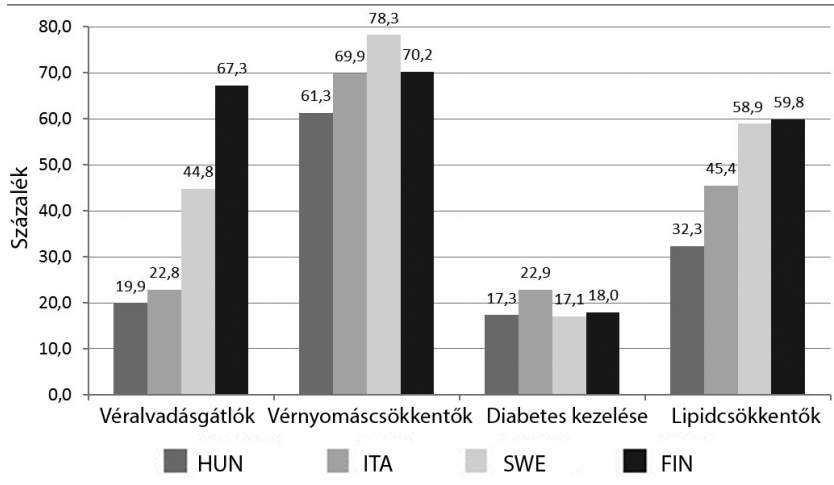

4. ábra

Gyógyszervásárlások kor és nem szerint standardizált aránya az indexfelvételt követő 365 napon belül a legalább 90 napot túlél ischaemiás stroke-betegek körében országonként* ${ }^{*} 2008$

*FIN = Finnország; HUN = Magyarország; ITA = Olaszország (Torino és Lazio tartomány); SWE = Svédország

Jelentősek az eltérések a kórházi ellátást követő gyógyszerek kiváltásában az elemzett országok között (4. ábra). Míg vérlemezke-összecsapzódást vagy véralvadást gátló szert a magyar betegek kevesebb mint 20\%-a vál- tott ki 2008-ban, a finnek több mint 60\%-a. A vérnyomáscsökkentő kiváltásának mértéke mind a négy országban 60\% fölött van, Svédországban majdnem eléri a 80\%-ot. Említést érdemel még a lipidcsökkentő alkalmazása, amely a magyar betegek körében volt a legalacsonyabb $(32,3 \%)$, a svéd és finn betegeknél ez 60\%-hoz közelít (4. ábra).

A kor és nem szerinti halálozási arányszámok jellegzetes különbségeket mutatnak hazánkban. A férfiak halálozása minden korcsoportban, mind a korai, mind a késői halálozásban magasabb a nőkénél. A fiatal férfiak életesélyei rosszabbak, mint a kései középkorban levőké. A korai és a kései halálozás görbéje jelentősen szétnyílik az életkor emelkedésével, ez a férfiak esetében korábbi években alakul ki és kifejezettebb (5. ábra). A strokebetegek kor és nem szerint kiegyenlített halálozása az időszakban mérsékelt csökkenést mutat. A 30 napos halálozás 2005-ben 16,2\%, 2009-ben 13,6\% volt, a 365 napos halálozás $31,6 \%$, illetve $27,2 \%$.

Nemzetközi vonatkozásban mind a 30, 90 és 365 napos halálozási mutatók Magyarországon voltak a legmagasabbak. A legkedvezőbb arányok Olaszországban voltak, de a svéd, finn és holland értékek is hasonló mértéküek. A hazai értékeket a skót adatok közelítik meg. A magyar halálozási adatok a legkedvezőbb olasz adatok kétszeresét teszik ki (6. ábra). Különösen szembetûnő, hogy Magyarországon a stroke után későn (a 30. és 365. nap között) bekövetkezett halálozás - Skócia kivételével - jóval meghaladja a többi európai ország értékeit.

\section{Megbeszélés}

A EuroHOPE tanulmány több országból származó nemzeti szintü, de egyéni lebontású komprehenzív adatbázist használt a stroke tényezőinek felmérésére, a nemzetközi adatok összehasonlítására. Az eredmények értelmezése során fontos kérdés a felhasznált adatok megbízhatósága és valóságtartalma. Ennek elemzéséhez korábbi tanulmányok eredményeit vizsgáltuk.

A kórházi kibocsátáskor adott diagnózisok érvényességét vizsgáló finn tanulmány [8] 80\%-os szenzitivitást, míg az analóg svédországi felmérés [9] 92\%-os szenzitivitást írt le. Egy szisztematikus magyarországi OEP-ellenőrzés [10] szerint az OEP-jelentésekben bármely pozícióban szereplő diagnózisok összességében több mint 99\%-ban megfelelnek a betegek zárójelentésében szereplő diagnózisoknak. A diagnózisok súlyozásában előfordulnak különbségek, amelyeket a mindenkori finanszírozási elóírások befolyásolnak, de elmondható, hogy az OEP felé bármely pozícióban jelentett stroke diagnózis esetén a páciensnek vélhetően stroke-ja volt. A fenti kutatás szerint az ischaemiás stroke, kórháztól függően, az esetek 54-84\%-ában ápolást indokló fódiagnózisként jelenik meg, tehát feltételezhetően akut esemény. Ennek a hibalehetőségnek a kiküszöbölésére, vagyis ahhoz, hogy az általunk vizsgált indexstroke valóban akut agyérka- 

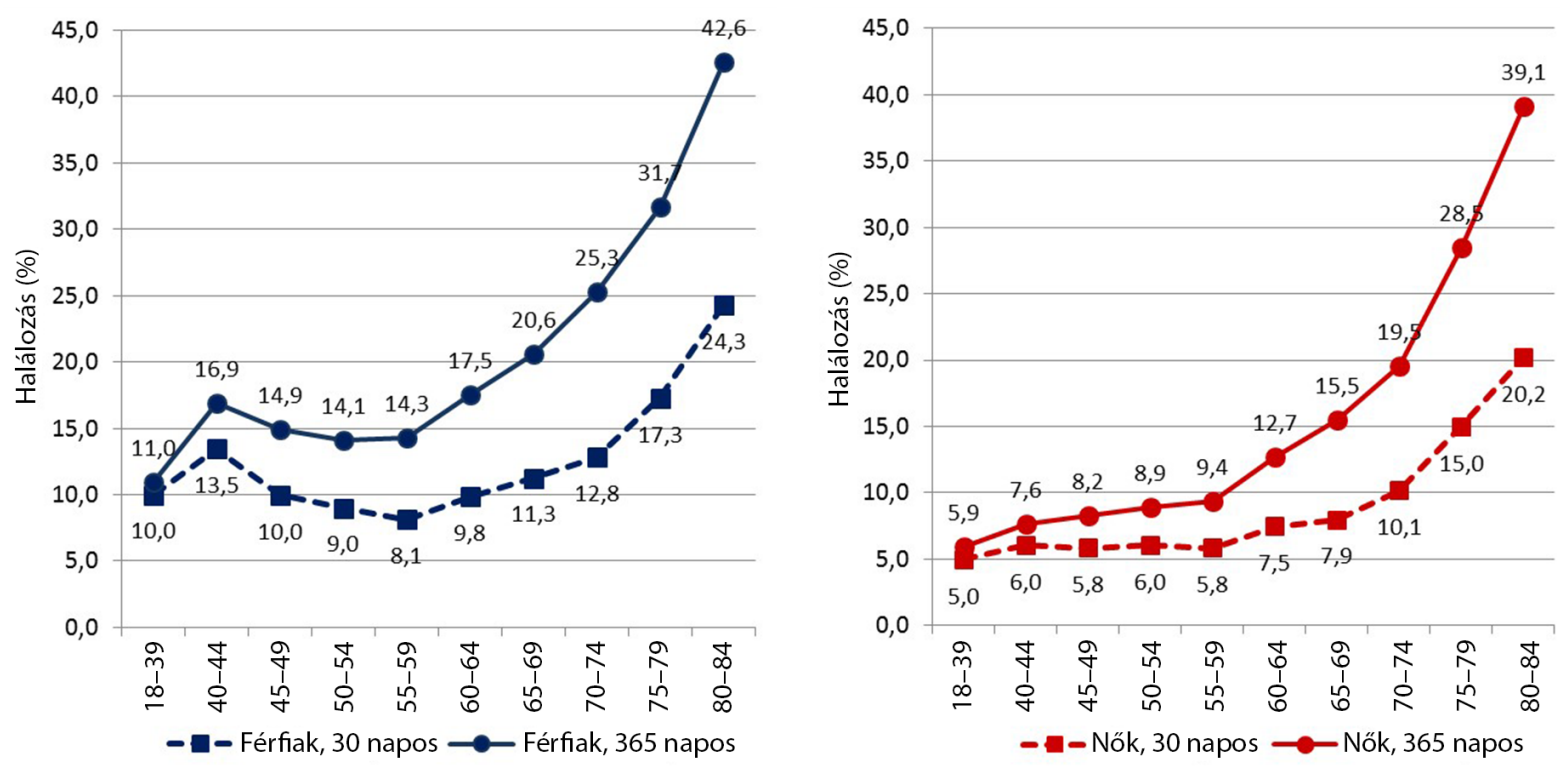

5. ábra

| Hospitalizált ischaemiás stroke-ot elszenvedett betegek 30 és 365 napos halálozása kor és nem szerint, 18-84 évesek, Magyarország 2009

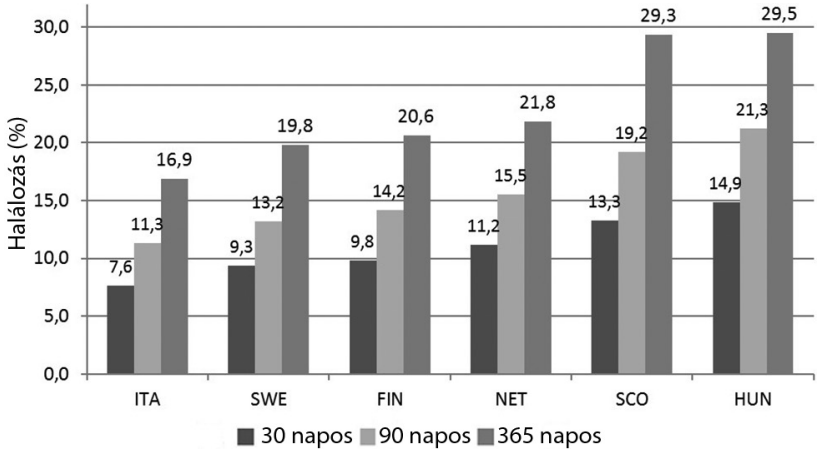

6. ábra

$\mid \begin{aligned} & \text { Hospitalizált ischaemiás stroke-betegek 30, } 90 \text { és } 365 \text { napos } \\ & \text { korra, nemre standardizált halálozása országonként }{ }^{*}, 2008 \\ & \text { *FIN = Finnország; HUN = Magyarország; ITA = Olaszország } \\ & \text { (Torino és Lazio tartomány); NET = Hollandia; SCO = Skócia; } \\ & \text { SWE = Svédország }\end{aligned}$

tasztrófának feleljen meg, a vizsgálatba azokat a 18 évnél idősebb betegeket vontuk be, akiknél az ápolást indokló fódiagnózis BNO 10-es kódja akut kórházi osztályon I60, I61, I63 vagy I64 volt, és a megelőző 365 napban nem volt ilyen födiagnózis kóddal ismert osztályos ellátásuk. A többi részt vevő ország kórházi adatbázisainak validitását mérố tanulmányok nem elérhetők vagy anekdotikusak.

Az, hogy a hospitalizált stroke-esetek mennyire tükrözik az összstroke-esetek adatait, szintén vitatható. Csak néhány országból érhetők el erre vonatkozó adatok [1113], ezek az országok 84-95\% közötti hospitalizációs arányt jelentettek. Skóciával és Hollandiával kapcsolatban feltételezhetô, hogy a hospitalizált stroke előfordulása jelentősen eltér az összstroke-esetektól, mivel számottevő az otthon ápolt esetek száma [4, 14].
Szintén torzíthatja az adatokat a stroke-altípusok téves vagy meg nem határozottként (BNO I64) történő jelentése, valamint a tranziens ischaemiás attak országonként eltérő kódolása (ez utóbbit - BNO G45 - nem vettük be a tanulmányba). Az I64 betegségkód aránya tanulmányunkban is változatos volt, ami szintén befolyásolhatja az eredmények validitását. Különösen a skóciai adatbázisban feltünően alacsony az ischaemiás stroke-esetek részaránya a többi országéhoz, valamint a populációs vizsgálatokhoz [15] képest. Feltételezhetően a kódolási gyakorlat különbözősége magyarázhatja ezt.

A tanulmány egyik hiányossága, amely az ischaemiás stroke halálozására vonatkozó eredményeinket befolyásolhatta, hogy nem voltak adataink a stroke súlyosságára vonatkozóan. Az egyes országokban a megelőzésben észlelt jelentős különbségek igen eltérő stroke-súlyossághoz vezethettek, a stroke súlyossága pedig a strokekimenetel ismert prediktív tényezője. Előfordulhat, hogy emiatt országunkban nemcsak a stroke-incidencia magasabb, hanem súlyosabbak is a bekövetkező agyérkatasztrófák $[15,16]$.

Összességében az alkalmazott módszerrel végzett stroke-incidencia-becslés jó közelítésnek tünik és alkalmas hasonló elemzések lebonyolítására.

Kevés információ áll rendelkezésre arról, hogy a kórházi regiszterek mennyire megbízhatóak a komorbiditás tekintetében. Ennek bizonytalanságát úgy korrigáltuk, hogy az indexstroke-ot megelőző egy évben az esetleges kórházi felvételek során rögzített egyéb betegségek adatait kiegészítettük az egyén ugyanezen évben kiváltott gyógyszerei alapján meghatározható betegségeivel. Az elemzett négy országban talált komorbiditási arányok erősen közelítenek egymáshoz és megfelelnek az ischaemiás stroke populációalapú felméréseiben jelentetteknek $[17,18]$. 
Miután a premorbid társbetegségekre vonatkozó információink részben a gyógyszervásárlási adatokból származnak, a stroke előtti komorbiditások aránya legalább részben a kezelt társbetegségekre vonatkozik. Ezek nagyságrendileg hasonlóak a vizsgált országok között. Tekintettel a magasabb magyarországi stroke-incidenciára és halálozásra, felmerül a kérdés: Vajon a kezeletlen komorbiditások figyelembevételével is ugyanerre az eredményre jutottunk volna?

Annál is jelentősebb lehet a fenti kérdés, mivel a stroke után kiváltott gyógyszerek aránya Magyarországon számottevően alacsonyabb, mint a többi országban. Ez a másodlagos prevencióban feltûnő hiányosság is befolyásolhatta a szintén magas hazai 365 napos halálozást. Szembetűnő a véralvadásgátlóként ható warfarin elenyésző (az 5 év során 1\% körüli) alkalmazása Magyarországon. $\mathrm{Az}$ acenocoumarol nem volt minden országban törzskönyvezve, így, sajnos, nem került be a vizsgált gyógyszerek listájára, annak ellenére, hogy a magyar országos gyógyszerforgalmi adatok szerint 2009-ben az acenocoumarolból kétszer több fogyott, mint a warfarinból (acenocoumarol: 9,022 millió DOT-érték, warfarin 4,077 millió DOT-érték). Ha hozzáadjuk a warfarinkiváltás értékéhez az itt nem vizsgált acenocoumarol kétszer gyakoribb használatát, még mindig csak körülbelül 3\% körülire tehető a véralvadásgátlóval kezelt ischaemiás stroke-ot elszenvedett betegek aránya, ami messze alulmarad a tanulmányunkban már a stroke előtt ismert 5\%-os pitvarfibrilláció-arányhoz képest is! Az ischaemiás stroke-os betegek körében a pitvarfibrilláció mint etiológiai tényező gyakorisága körülbelül 15-20\%-ra tehető [19-21]. Ilyenformán ennek a betegcsoportnak hozzávetőleg 10-15\%-a kap megfelelő kezelést. A premorbid társbetegségek gyakoriságát nem éri el a stroke-ot követő gyógyszerkiváltás aránya, tehát a komorbiditás jó része a stroke-ot követően is kezeletlen marad. Adataink alapján Magyarországon a stroke előtt és a stroke után kiváltott gyógyszerek aránya nem különbözik jelentősen. Ez ismét a másodlagos prevenció elégtelenségére utal.

A lakosságalapú stroke-incidenciát becslő tanulmányokkal [22, 23] összehasonlítva a EuroHOPE által talált stroke-incidencia alacsonyabb volt, ami a már fentebb kifejtett okokkal függhet össze (a hospitalizációs ráta és a kódolási módszerek befolyásolhatták az általunk talált incidenciát). A különbséget részben az is magyarázhatja, hogy a lakosságalapú felmérések korábban készültek, mint a EuroHOPE tanulmány, és a stroke-incidencia csökkenhetett az ismert tendenciának megfelelően [3].

A EuroHOPE tanulmányban részt vett országok stroke-incidencia-adatait egymással hasonlítva össze, látványos, de már ismert [22] a különbség Magyarország kárára: a magyar stroke-incidencia kétszerese a finn és svéd értéknek. A skóciai, kirívóan alacsony stroke-incidencia, a szokatlanul alacsony ischaemiásstroke-rátával párosulva számottevően eltér a Nagy-Britanniában jelentett értékektől [15]. Ez felveti az inherens adatbázishiba vagy az eltérő kódolási szokások lehetőségét.

\section{Következtetés}

A hazai elkeserítő halálozási adatok több problémát vetnek fel. A többi európai országhoz képest magasabb korai halálozás a hazai elsődleges prevenció hiányosságára, az akut stroke-betegek feltételezhetően súlyosabb állapotára utalhat. Az akut esemény során szintén meghatározó szerepe van a diagnózis időben történő felismerésének, az adekvát terápia alkalmazásának, az ápolás minőségének. Bár a tendencia javul, Magyarországon jelentősen több beteg hal meg az első 30 napot követően, illetve a stroke utáni 1 év során, mint a többi vizsgált országban. Az említett, 365 napos halálozást nemcsak a premorbid és a kórházi ellátás befolyásolhatja. Ebben mutatkozhat meg a korai mobilizálás elkezdésének és fenntartásának (a rehabilitációnak) a hiánya vagy nem megfelelősége, a kórházi eltávozást követő időszakban zajló ellátási nehézségek, a gyógyszerszedés adherenciájának hiánya, vagyis összességében a másodlagos prevenció általunk is észlelt kudarca. Ezt tovább fokozhatja a Magyarországon dolgozó szakemberek egyre növekvő hiánya és leterheltsége.

Anyagi támogatás: A szerzők közül B. D. és B. É. a közlemény alapját képező ismeretek összegyújtéséért az Európai Unió 7 . keretprogramjának 241721. számú szerződése szerint a European Health Care Outcomes, Performance and Efficiency (EuroHOPE) projekt keretében anyagi támogatásban részesült.

Szerzôi munkamegosztás: Sz. I., B. D.: Szakirodalmi áttekintés, a szakmai hangsúlyok kiemelése, az eredmények értelmezése, a következtetések megfogalmazása, a közlemény összeállítása. B. É.: Adatfeldolgozás, -elemzés, a kutatás hazai irányítása, a közlemény összeállítása. A cikk végleges változatát valamennyi szerző elolvasta és jóváhagyta.

Érdekeltségek: A szerzők aktívan részt vettek a EuroHOPE kutatási projektben és a kutatás folytatásaként zajló BRIDGE projektben.

\section{Irodalom}

[1] Levi, F., Chatenoud, L., Bertuccio, P., et al.: Mortality from cardiovascular and cerebrovascular diseases in Europe and other areas of the world: an update. Eur. J. Cardiovasc. Prev. Rehabil., 2009, 16(3), 333-350.

[2] Roger, V. L., Go, A. S., Lloyd-Jones, D. M., et al.: Heart disease and stroke statistics - 2012 update. A report from the American Heart Association. Circulation, 2012, 125(1), e2-e220.

[3] World Health Organization Regional Office for Europe: European mortality database (MDB), Updated: December 2015.

[4] Malmivaara, A., Meretoja, A., Peltola, M., et al.: Comparing ischaemic stroke in six European countries. The EuroHOPE register study. Eur. J. Neurol., 2014, 22(2), 284-291.

[5] www.stats.oecd.org

[6] Häkkinen, U., Iversen, T., Peltola, M., et al.: Health care performance comparison using a disease-based approach: The EuroHOPE project. Health Policy, 2013, 112(1-2), 100-109. 
[7] Malmivaara, A.: EuroHOPE stroke: material, methods and indicators. EuroHOPE Discussion Papers No. 6. http://www.eurohope.info/doc/EHDP6_Stroke.pdf

[8] Sund, R.: Quality of the Finnish Hospital Discharge Register: a systematic review. Scand. J. Public Health, 2012, 40(6), 505515.

[9] Köster, M., Asplund, K., Johansson, Å., et al.: Refinement of Swedish administrative registers to monitor stroke events on the national level. Neuroepidemiology, 2013, 40(4), 240-246.

[10] Ajtay, A., Oberfrank, F., Bereczki, D.: Applicability of hospital reports submitted for reimbursement purposes for epidemiological studies based on the example of ischemic cerebrovascular diseases. [A kórházi adatlapok jelentéseinek alkalmazhatósága epidemiológiai elemzésekre az ischaemiás cerebrovascularis betegségek példája alapján.] Orv. Hetil., 2015, 156(38), 15401546.

[11] Mähönen, M., Salomaa, V., Keskimäki, I., et al.: The feasibility of combining data from routine Hospital Discharge and Causes-ofDeath Registers for epidemiological studies on stroke. Eur. J. Epidemiol., 2000, 16(9), 815-817.

[12] Tancioni, V., Collini, F., Balzi, D., et al.: Acute stroke incidence estimated using a standard algorithm based on electronic health data in various areas of Italy. Epidemiol. Prev., 2008, 32(3 Suppl.), $38-45$.

[13] Stegmayr, B., Asplund, K.: Stroke in Northern Sweden. Scand. J. Public Health, 2003, 61(Suppl.), 60-69.

[14] Turner, M., Barber, M., Dodds, H., et al., on behalf of the Scottish Stroke Care Audit: Agreement between routine electronic hospital discharge and Scottish Stroke Care Audit (SSCA) data in identifying stroke in the Scottish population. BMC Health Serv. Res., 2015, 15, 583.

[15] Stroke Association Workgroup: Stroke statistics 2013. Stroke Association Resource sheet 11, version 1. http://www.thepossibilities.co.uk/assets/downloads/stroke-statistics.pdf
[16] Feigin, V. L., Forouzanfar, M. H., Krishnamurthi, R., et al.: Global and regional burden of stroke during 1990-2010: findings from the Global Burden of Disease Study 2010. Lancet, 2014, 383(9913), 245-254.

[17] Heuschmann, P. U., Di Carlo, A., Bejot, Ү., et al., on behalf of European Registers of Stroke (EROS) Investigators: Incidence of stroke in Europe at the beginning of the 21 st century. Stroke, 2009, 40(5), 1557-1563.

[18] Rothwell, P. M., Coull, A. J., Silver, L. E., et al.: Population-based study of event-rate, incidence, case fatality, and mortality for all acute vascular events in all arterial territories (Oxford Vascular Study). Lancet, 2005, 366(9499), 1773-1783.

[19] Arboix, A., Alio, J.: Acute cardioembolic cerebral infarction: Answers to clinical questions. Curr. Cardiol. Rev., 2012, 8(1), 5467.

[20] Bereczki, D., Mihálka, L., Fekete, I., et al.: The Debrecen Stroke Database: demographic characteristics, risk factors, stroke severity and outcome in 8088 consecutive hospitalised patients with acute cerebrovascular disease. Int. J. Stroke, 2009, 4(5), 335339.

[21] Orbán-Kis, K., Szöcs, I., Fekete, K., et al.: Comparison of hospitalized acute stroke patients' characteristics using two large Central-eastern European databases. Ideggyogy. Sz., 2016, 69(1-2), 47-53.

[22] Truelsen, T., Piechowski-Jóźwiak, B., Bonita, R., et al.: Stroke incidence and prevalence in Europe: a review of available data. Eur. J. Neurol., 2006, 13(6), 581-598.

[23] Feigin, V. L., Lawes, C. M., Bennett, D. A., et al.: Worldwide stroke incidence and early case fatality reported in 56 population-based studies: a systematic review. Lancet Neurol., 2009, $8(4), 355-369$.

(Belicza Éva dr., Budapest, Kútvölgyi út 2., 1125 e-mail: belicza@emk.sote.hu)

\section{$\triangle$ DEKRA}

\section{Alapozza meg szakmai karrierjét Svájcban! Kiváló lehetőség}

\section{orvosok számára!}

Svájci kórházakba, klinikákra keresünk szakorvosokat (belgyógyász, aneszteziológus, stb.) tárgyalási szintű német/angol nyelvtudással. Vezetői munkakörbe is, kiemelt bérezéssel.

Érdeklődés esetén lehetőség, várjuk önéletrajzát.

dekra@dekra-arbeit.hu 